\title{
Color of Vertically-Suspended Structure Does Not Impact the Growth of Rainbow Trout Reared in Circular Tanks
}

\author{
Edgar Meza, Misty D. Jones, Nathan Huysman, Jill M. Voorhees, Michael E. Barnes \\ Department of Game, Fish, and Parks, McNenny State Fish Hatchery, Spearfish, South Dakota, USA \\ Email: mike.barnes@state.sd.us
}

How to cite this paper: Meza, E., Jones, M.D., Huysman, N., Voorhees, J.M. and Barnes, M.E. (2020) Color of Vertically-Suspended Structure Does Not Impact the Growth of Rainbow Trout Reared in Circular Tanks. Open Journal of Animal Sciences, 10, 706-713.

https://doi.org/10.4236/ojas.2020.104045

Received: August 22, 2020

Accepted: October 6, 2020

Published: October 9, 2020

Copyright $\odot 2020$ by author(s) and Scientific Research Publishing Inc. This work is licensed under the Creative Commons Attribution International License (CC BY 4.0).

http://creativecommons.org/licenses/by/4.0/ (c) (i) Open Access

\begin{abstract}
This study examined the effects of five different colors of vertically-suspended environmental enrichment on the growth of juvenile Shasta strain rainbow trout (Oncorhynchus mykiss) during hatchery rearing in circular tanks. The colors used were silver (unpainted aluminum-control), safety red, semi-gloss black, hunter green, and safety blue. After 86 days, total tank weight, weight gain, and feed conversion ration were not significantly different among any of the color treatments. Individual fish weights, lengths, and condition factors were also not significantly different among the treatments. The results of this study indicate that the relatively small amount of color present on the suspended structure did not affect rainbow trout growth. Thus, the inherent silver color of the aluminum angles does not need to be changed.
\end{abstract}

\section{Keywords}

Environmental Enrichment, Oncorhynchus mykiss, Salmonids, Color

\section{Introduction}

Color can impact fish reared in an artificial setting. The colors used during hatchery rearing likely affect growth, stress response, aggression, and body coloration [1]-[6]. However, these results are not uniform, indicating specific colors affect species differently. Blue has been shown to negatively affect the growth of rainbow trout (Oncorhynchus mykiss), but positively affect the growth of gilthead seabream (Sparus aurata) [7]. Pale colored tanks (white or beige) have led to increased weight gain in goldfish (Carassius auratus) [4] and rainbow trout [8], but negatively impacted weight gain in African catfish (Heterobrachuys bidorsalis) [9]. 
Hatchery rearing performance can also be influenced by the addition of real or synthetic materials into barren hatchery tanks as a form of environmental enrichment [10] [11] [12] [13]. The possible interaction between such structures and color has only been lightly studied. In a study comparing blue substrate, a photo of blue substrate, and a control, Batzina and Karakatsouli [14] observed that combination of both color and actual substrate produced the only positive effects. Jones et al. [15] reported an increase in landlocked juvenile Chinook salmon (Oncorhynchus tshawytscha) growth when reared with vertically-suspended arrays of aluminum angles painted green compared to arrays painted silver, red, or black. In contrast, Chapman et al. [16] reported no effects of different colored vertically-suspended arrays during the rearing of rainbow trout.

The Chapman et al. [16] and Jones et al. [15] studies were of very short duration, lasting only 54 days and 25 days, respectively. Neither of these studies lasted as long as the minimum study duration of 56 to 84 days recommended by the National Research Council [17] for fish feeding trials. Thus, the objective of this study was to evaluate the use of different colored vertically-suspended arrays during the longer-term rearing of rainbow trout.

\section{Methods}

This 86-day experiment was conducted at McNenny State Fish Hatchery, rural Spearfish, South Dakota, USA, using single-pass, degassed and aerated well water at a constant temperature of $11^{\circ} \mathrm{C}$ (water hardness as $\mathrm{CaCO}_{3}=360 \mathrm{mg} / \mathrm{L}$, alkalinity as $\mathrm{CaCO}_{3}=210 \mathrm{mg} / \mathrm{L}, \mathrm{pH}=7.6$, total dissolved solids $\left.=390 \mathrm{mg} / \mathrm{L}\right)$. On June 24, 2019, 20 circular tanks (diameter $=1.8 \mathrm{~m}$, height $=0.8 \mathrm{~m}$, water depth $=$ $0.6 \mathrm{~m}$ ) each received $23.1 \mathrm{~kg}$ of Shasta strain rainbow trout (approximately 3,500 fish). Individual trout mean $\pm \mathrm{SE}$ total lengths and weights were $78 \pm 2 \mathrm{~mm}$ and $5.1 \pm 0.4 \mathrm{~g}(n=30)$, respectively. Each tank was nearly fully covered with black corrugated plastic [18]. An array of four aluminum angles (each side $2.5 \mathrm{~cm}$ wide, $57.15 \mathrm{~cm}$ long) were suspended from the overhead covers as described by Krebs et al. [19].

The four angles of the array were all the same color in each tank. The colors of the angles were silver (unpainted aluminum, which acted as a control), safety red, semi-gloss black, hunter green, or safety blue. Treatments were randomly assigned with each colored array replicated in four tanks (20 total tanks with four tanks per color). The red and blue arrays were created by uniformly painting the angles with OSHA standard colored spray paint (Krylon, Krylon Products Group, Cleveland, Ohio, USA). The black and green arrays were created by spray painting the angles with gloss enamel (Rust-oleum, Rust-oleum Corporation, Illinois, USA). A MiniScan XE Plus spectrophotometer (HunterLab, Reston, Virginia, USA) was used to obtain digital color values for the colors of the tank and structures (Table 1).

All fish were fed 1.5-mm extruded floating feed (Protec, Skretting, Toole, Utah, USA) daily over an 8-hour period in 20-minute intervals using automatic 
Table 1. Color value measurements taken with the MiniScan XE Plus. The top row is the color of the tanks, and the following are colors of the aluminum angles used in the array.

\begin{tabular}{cccc}
\hline Color & $L$ & $a^{*}$ & $b^{*}$ \\
\hline Blue-green & 50.41 & -46.19 & 1.35 \\
Silver & 71.48 & -1.92 & 2.01 \\
Red & 31.89 & 49.84 & 26.27 \\
Black & 9.14 & -0.99 & 1.18 \\
Green & 26.54 & -23.39 & 12.57 \\
Blue & 33.29 & -7.22 & -37.26 \\
\hline
\end{tabular}

feeders. The hatchery constant method [20] was used to determine feeding rates at or slightly above satiation, with a projected growth rate of $0.08 \mathrm{~cm} /$ day.

Total tank weights were recorded to the nearest $0.2 \mathrm{~kg}$ using an Intercomp CS200 hanging scale (Medina, Minnesota, USA) at the end of the experiment. Also, at the end of the study, five randomly sampled fish from each tank were weighed to the nearest $0.1 \mathrm{~g}$ and total length measured to the nearest $1.0 \mathrm{~mm}$. The following equations were used:

$$
\begin{gathered}
\text { Gain = final tank weight }- \text { initial tank weight. } \\
\text { Feed conversion ratio }(\mathrm{FCR})=\text { feed fed/gain. } \\
\text { Condition factor } \left.(K)=10^{5} \times[\text { weight } / \text { (body length })^{3}\right] .
\end{gathered}
$$

One-way Analysis of Variance (ANOVA) was used to analyze the data with the SPSS (24.0) statistical analysis program (IBM, Armonk, New York, USA). Because the tanks were the experimental units, not individual fish, nested ANOVA was conducted on the individual fish data. Significance was pre-determined at $p$ $<0.05$.

\section{Results}

Total tank ending weight, gain, and feed conversion ratio were not significantly different among any of the color treatments (Table 2). Individual fish weights, lengths, and condition factors were also not significantly different among the treatments (Table 3).

\section{Discussion}

The results from this study support those of Chapman et al. [16], who concluded that the color of vertically-suspended environmental enrichment had no impact on juvenile rainbow trout growth during hatchery rearing. However, these results differ from Luchiari and Pirhonen [21] who reported increased rainbow trout growth in green environments, compared to blue, red, white, or yellow. Contrarily, Karakatsouli et al. [7] [22] observed increased rainbow trout growth using red light, while Papoutsoglou et al. [23] noted reduced rainbow trout growth in black tanks. Lastly, Üstündağ and Rad [8] reported increased rainbow 
Table 2. Mean \pm SE tank total weights, gain, food fed, and feed conversion ratios $\left(F^{2}{ }^{a}\right)$ for rainbow trout reared with different colored enrichment structures $(n=4)$.

\begin{tabular}{ccccccc}
\hline Color & Silver & Red & Black & Green & Blue & $p$-value \\
\hline Final weight (kg) & $121.0 \pm 1.5$ & $115.1 \pm 4.2$ & $120.0 \pm 3.8$ & $121.0 \pm 2.0$ & $127.1 \pm 2.7$ & 0.182 \\
Gain (kg) & $99.1 \pm 2.5$ & $93.9 \pm 3.8$ & $98.2 \pm 3.9$ & $100.2 \pm 2.1$ & $104.7 \pm 2.9$ & 0.235 \\
Food fed (kg) & 127 & 127 & 127 & 127 & 127 & \\
FCR & $1.30 \pm 0.03$ & $1.38 \pm 0.05$ & $1.32 \pm 0.05$ & $1.29 \pm 0.03$ & $1.23 \pm 0.04$ & 0.220 \\
Mortality (\%) & $1.03 \pm 0.40$ & $1.87 \pm 0.56$ & $1.42 \pm 0.56$ & $2.00 \pm 0.27$ & $0.54 \pm 0.19$ & 0.141 \\
\hline
\end{tabular}

${ }^{\mathrm{a}} \mathrm{FCR}=$ food fed/gain.

Table 3. Mean \pm SE fish individual total lengths, weights, and condition factors $\left(K^{\mathrm{a}}\right)$ for rainbow trout reared with different colored enrichment structures $(n=4)$.

\begin{tabular}{ccccccc}
\hline Color & Silver & Red & Black & Green & Blue & $p$-value \\
\hline Length $(\mathrm{mm})$ & $146 \pm 5$ & $146 \pm 5$ & $150 \pm 3$ & $146 \pm 3$ & $146 \pm 2$ & 0.895 \\
Weight $(\mathrm{g})$ & $36.1 \pm 4.2$ & $34.2 \pm 3.5$ & $36.7 \pm 2.5$ & $36.0 \pm 2.5$ & $37.5 \pm 2.2$ & 0.956 \\
K & $1.15 \pm 0.03$ & $1.08 \pm 0.04$ & $1.08 \pm 0.01$ & $1.16 \pm 0.03$ & $1.19 \pm 0.03$ & 0.056 \\
\hline
\end{tabular}

${ }^{\mathrm{a}} \mathrm{K}=10^{5} \times$ individual weight/body length ${ }^{3}$.

trout growth in beige tanks compared to green or gray-colored tanks. These inconsistent and apparently contradictory results may be due to several reasons, including the amount of color present in the rearing unit, light intensity, water temperature, study duration, and the sizes and strains of rainbow trout used.

The relatively small surface area of the vertically-suspended structure used in this study in relation to the much larger tank surfaces may not have provided enough color to elicit a response from the trout [16]. In addition, the tanks in this study were covered, which eliminated most of the ambient light. Although this has been shown to positively impact trout growth [18], the interaction of such a low light intensity and small area of color may have impacted the ability of the trout retina to detect color differences [23].

At 86 days, this study exceeded the recommended duration for fish feeding trials by the National Research Council [17]. It was also 32 days longer than the Chapman et al. [16] study which also reported no significant effect of suspended structure color on rainbow trout growth during hatchery rearing. It is possible that this study lasted too long in relation to fish rearing densities. Voorhees et al. [24] and Huysman et al. [25] suggested that high rearing densities, such as those observed at the end of this study, may lead to density-dependent reduced growth rates. By allowing fish in the slower-growing treatments the time to catch up in size to those fish in faster-growing treatments that reach higher densities more quickly, longer study durations may preclude the determination of significant differences among treatments. However, because both this study and the much shorter Chapman et al. [16] experiment both were unable to detect any structural color impacts, it is unlikely that the results were impacted by rearing density. 
The rainbow trout in this study were reared in a constant $11^{\circ} \mathrm{C}$ water temperature, which may have influenced the results. Rainbow trout color preferences may be temperature dependent. Luchiari and Pirhonen [21] reported a color preference shift in rainbow trout from green at $12^{\circ} \mathrm{C}$ to blue at $1^{\circ} \mathrm{C}$. Differences in temperature may also explain some of the previously noted differences among prior studies such as Papoutsoglou et al. [23], Karakatsouli et al. [7] [22], Luchiari and Pirhonen [21], and Üstündağ and Rad [8].

The results of this study are likely unique to the size and genetic strain of rainbow trout used. Salmonid color preferences may change with developmental stage over time [26] [27]. In addition, given the differences in color preferences among salmonids [5] [7] [8] [15] [21] [22] [23], and among different fish species [1] [2] [3] [4] [6] [9] [14] [28] [29] [30], it is possible that different rainbow trout strains would react differently to different colors.

Lastly, the source of color may have influenced the results of this study. $\mathrm{Nu}$ merous other color investigations during fish rearing have focused on the color of the entire tank [2] [4] [6] [23] [31], rather than on structure within an already-colored tank. Lighting has also been used as a source of color, with fish held in tanks that match the color of the light source or tanks that are opaque or colorless [7] [22] [32] [33].

\section{Conclusion}

In conclusion, the results of this study indicate that the color of vertically-suspended environmental enrichment structures likely has little impact on rainbow trout growth in covered circular tanks. Thus, the inherent silver (unpainted aluminum) color of such structures does not need to be changed to produce additional rainbow trout rearing benefits beyond those of just using the structures themselves [19] [34] [35] [36] [37] [38]. Additional research investigating the effects of environmental enrichment colors should be conducted with other fish species and sizes.

\section{Acknowledgements}

Thanks to Sierra Frazier, Shaylee Martling, Angel Munoz, Aaron Chapman, Lynn Slama, and Jessica Shannon for their assistance with this study.

\section{Conflicts of Interest}

The authors declare no conflicts of interest regarding the publication of this paper.

\section{References}

[1] Volpato, G.L. and Barreto, R.E. (2001) Environmental Blue Light Prevents Stress in the Fish Nile Tilapia. Brazilian Journal of Medical and Biological Research, 34, 1041-1045. https://doi.org/10.1590/S0100-879X2001000800011

[2] Strand, Å., Alanärä, A., Staffan, F. and Magnhagen, C. (2007) Effects of Tank Colour and Light Intensity on Feed Intake, Growth Rate and Energy Expenditure of 
Juvenile Eurasian Perch, (Perca fluviatilis L.). Aquaculture, 272, 312-318. https://doi.org/10.1016/j.aquaculture.2007.08.052

[3] Qin, G., Lin, Q., Gu, N., Lin, J.D. and Huang, L.M. (2012) Effect of Broodstock Origin, Background and Substrate Color on Skin Coloration of Three-Spotted Seahorses Hippocampus trimaculatus Leach, 1814. Journal of Experimental Marine Biology and Ecology, 416, 129-134. https://doi.org/10.1016/j.jembe.2012.02.007

[4] Eslamloo, K., Akhavan, S.R., Eslamifar, A. and Henry, M.A. (2015) Effects of Background Colour on Growth Performance, Skin Pigmentation, Physiological Condition and Innate Immune Responses of Goldfish, Carassius auratus. Aquaculture Research, 46, 202-215. https://doi.org/10.1111/are.12177

[5] Gaffney, L.P., Franks, B. and Weary, D.M. (2016) Coho Salmon (Oncorhynchus kisutch) Prefer and Are Less Aggressive in Darker Environments. PLoS ONE, 11, e0151325. https://doi.org/10.1371/journal.pone.0151325

[6] Ghavidel, S., Kochanian, P. and Salati, A.P. (2020) The Effects of Tank Color on Growth Performance and Physiological Responses in Fingerling Grouper, Epinephelus coioides. Aquaculture Research, 51, 276-281.

https://doi.org/10.1111/are.14373

[7] Karakatsouli, N., Papoutsoglou, S.E., Pizzonia, G., Tsatsos, G., Tsopelakos, A., Chadio, S., Kalogiannis, D., Dalla, C., Polissidis, A. and Papadopoulou-Daifoti, Z. (2007) Effects of Light Spectrum on Growth and Physiological Status of Gilthead Seabream Sparus aurata and Rainbow Trout Oncorhynchus mykiss Reared under Recirculating System Conditions. Aquaculture Engineering, 36, 302-309. https://doi.org/10.1016/j.aquaeng.2007.01.005

[8] Üstündağ, M. and Rad, F. (2015) Effect of Different Tank Colors on Growth Performance of Rainbow Trout Juvenile (Oncorhynchus mykiss Walbaum, 1792). Journal of Agricultural Sciences, 21, 144-150. https://doi.org/10.15832/tbd.15181

[9] Solomon, J.R. and Ezigbo, M.N. (2018) Effects of Background Tank Colour on the Growth and Survival of Juvenile Heterobrachus bidorsalis Fed Coppens and Tamarindus indica meal. Tropical Freshwater Biology, 27, 63-84.

https://doi.org/10.4314/tfb.v27i1.6

[10] Berejikian, B.A., Tezak, E.P., Flagg, T.A., LaRae, A.L., Kummerow, E. and Mahnken, C.V.W. (2000) Social Dominance, Growth, and Habitat Use of Age-0 Steelhead (Oncorhynchus mykiss) Grown in Enriched and Conventional Hatchery Rearing Environments. Canadian Journal of Fisheries and Aquatic Sciences, 57, 628-636. https://doi.org/10.1139/f99-288

[11] Berejikian, B.A. and Tezak. E.P. (2005) Rearing in Enriched Hatchery Tanks Improves Dorsal Fin Quality of Juvenile Steelhead. North American Journal of Aquaculture, 67, 289-293. https://doi.org/10.1577/A05-002.1

[12] Näslund, J., Rosengren, M., Del Villar, D., Gansel, L., Norrgård, J.R., Persson, L., Winkowski, J.J. and Kvingedal, E. (2013) Hatchery Tank Enrichment Affects Cortisol Levels and Shelter-Seeking in Atlantic Salmon (Salmo salar). Canadian Journal of Fisheries and Aquatic Sciences, 70, 585-590.

https://doi.org/10.1139/cjfas-2012-0302

[13] Roberts, L.J., Taylor, J., Gough, P.J., Forman, D.W. and Garcia de Leaniz, D.W. (2014) Silver Spoons in the Rough: Can Environmental Enrichment Improve Survival of Hatchery Atlantic Salmon (Salmo salar) in the Wild? Journal of Fish Biolo$g y, 85,1972-1991$. https://doi.org/10.1111/jfb.12544

[14] Batzina, A. and Karakatsouli, N. (2014) Is It the Blue Gravel Substrate or Only Its Blue Color that Improves Growth and Reduces Aggressive Behavior of Gilthead 
Seabream Sparus aurata. Aquaculture Engineering, 62, 49-53.

https://doi.org/10.1016/j.aquaeng.2014.06.004

[15] Jones, M.D., Voorhees, J.M., Huysman, N., Krebs, E. and Barnes, M.E. (2020) Use of Different Colours of Vertically-suspended Structure during the Hatchery Rearing of Juvenile Landlocked Fall Chinook Salmon (Oncorhynchus tshawytscha, Walbaum). International Journal of Fisheries and Aquaculture, 12, 21-25. https://doi.org/10.5897/IJFA2019.0762

[16] Chapman, A., Huysman, N., Voorhees, J.M., Krebs, E. and Barnes, M.E. (2020) Color of Vertically-Suspended Environmental Enrichment Does Not Effect Juvenile Rainbow Trout Growth during Hatchery Rearing. International Journal of Fisheries and Aquatic Studies, 8, 32-36.

[17] National Research Council (2011) Nutrient Requirements of Fish. National Academy Press, Washington DC.

[18] Walker, L.M., Parker, T.M. and Barnes, M.E. (2016) Full and Partial Overhead Tank Cover Improves Rainbow Trout Rearing Performance. North American Journal of Aquaculture, 78, 20-24. https://doi.org/10.1080/15222055.2015.1090504

[19] Krebs, E., Huysman, N., Voorhees, J.M. and Barnes, M.E. (2018) Suspended Arrays Improve Rainbow Trout Growth during Hatchery Rearing in Circular Tanks. International Journal of Aquaculture and Fishery Sciences, 4, 27-30.

[20] Buterbaugh, G.L. and Willoughby, H. (1967) A Feeding Guide for Brook, Brown, and Rainbow Trout. The Progressive Fish-Culturist, 29, 210-215.

https://doi.org/10.1577/1548-8640(1967)29[210:AFGFBB]2.0.CO;2

[21] Luchiari, A.C. and Pirhonen, J. (2008) Effects of Ambient Colour on Colour Preference and Growth of Juvenile Rainbow Trout Oncorhynchus mykiss (Walbaum). Journal of Fish Biology, 72, 1504-1514. https://doi.org/10.1111/j.1095-8649.2008.01824.x

[22] Karakatsouli, N., Papoutsoglou, S.E., Panopoulos, G., Papoutsoglou, E.S., Chadio, S. and Kalogiannis, D. (2008) Effects of Light Spectrum on Growth and Stress Response of Rainbow Trout Onchorhynchus mykiss Reared under Recirculating System Conditions. Aquaculture Engineering, 38, 36-42. https://doi.org/10.1016/j.aquaeng.2007.10.006

[23] Papoutsoglou, S.E., Karakatsouli, N. and Chiras, G. (2005) Dietary L-Tryptophan and Tank Colour Effects on Growth Performance of Rainbow Trout (Oncorhynchus mykiss) Juveniles Reared in a Recirculating Water System. Aquacultural Engineering, 32, 277-284. https://doi.org/10.1016/j.aquaeng.2004.04.004

[24] Voorhees, J.M., Huysman, N., Krebs, E. and Barnes, M.E. (2020) Use of Exercise and Structure during Rainbow Trout Rearing. Open Journal of Applied Sciences, 10, 258-269. https://doi.org/10.4236/ojapps.2020.105020

[25] Huysman, N., Krebs, E., Voorhees, J.M. and Barnes, M.E. (2019) Use of Two Vertically-Suspended Environmental Enrichment Arrays during Rainbow Trout Rearing in Circular Tanks. International Journal of Innovative Studies in Aquatic Biology and Fisheries, 5, 25-30. https://doi.org/10.20431/2454-7670.0501005

[26] Beatty, D.D. (1966) A Study in the Succession of Visual Pigments in Pacific Salmon (Oncorhynchus). Canadian Journal of Zoology, 44, 429-455. https://doi.org/10.1139/z66-045

[27] Flamarique, I.N. (2005) Temporal Shifts in Visual Pigment Absorbance in the Retina of Pacific Salmon. Journal of Comparative Physiology A, 191, 37-49. https://doi.org/10.1007/s00359-004-0573-9

[28] Batzina, A. and Karakatsouli, N. (2012) The Presence of Substrate as a Means of 
Environmental Enrichment in Intensively Reared Gilthead Seabream Sparus aurata: Growth and Behavioral Effects. Aquaculture, 370-371, 54-60. https://doi.org/10.1016/j.aquaculture.2012.10.005

[29] Batzina, A. and Karakatsouli, N. (2014) The Preference of 0+ and 2+ Gilthead Seabream Sparus aurata for Coloured Substrates or No-Substrate. Applied Animal Behaviour Science, 151, 110-116. https://doi.org/10.1016/j.applanim.2013.11.013

[30] Mat Nawang, S.U.S., Ching, F.F. and Senoo, S. (2019) Comparison on Growth Performance, Body Coloration Changes and Stress Response of Juvenile River Catfish, Pangasius hypophthalmus Reared in Different Tank Background Colour. Aquaculture Research, 50, 2591-2599. https://doi.org/10.1111/are.14215

[31] Browman, H.I. and Marcotte, B.M. (1987) Effects of Prey Color and Background Color on Feeding by Atlantic Salmon Alevins. The Progressive Fish-Culturist, 49, 140-143. https://doi.org/10.1577/1548-8640(1987)49\%3C140:EOPCAB\%3E2.0.CO;2

[32] Banan, A., Kalbassi, M.R., Bahmani, M. and Sadati, M.A.Y. (2011) Effects of Colored Light and Tank Color on Growth Indices and Some Physiological Parameters of Juvenile Beluga (Huso huso). Journal of Applied Ichthyology, 27, 565-570. https://doi.org/10.1111/j.1439-0426.2011.01682.x

[33] Elnwishy, N., Sabri, D. and Nwonwu, F. (2012) The Effect of Difference in Environmental Colours on Nile Tilapia (Oreochromis niloticus) Production Efficiency. International Journal of Agriculture Biology, 14, 516-520.

[34] Kientz, J. and Barnes, M.E. (2016) Structural Complexity Improves the Rearing Performance of Rainbow Trout in Circular Tanks. North American Journal of Aquaculture, 78, 203-207. https://doi.org/10.1080/15222055.2016.1159629

[35] Kientz, J., Crank, K.M. and Barnes, M.E. (2018) Enrichment of Circular Tanks with Vertically Suspended Strings of Colored Balls Improves Rainbow Trout Rearing Performance. North American Journal of Aquaculture, 80, 162-167. https://doi.org/10.1002/naaq.10017

[36] White, S.C., Krebs, E., Huysman, N., Voorhees, J.M. and Barnes, M.E. (2019) Use of Suspended Plastic Conduit Arrays during Brown Trout and Rainbow Trout Rearing in Circular Tanks. North American Journal of Aquaculture, 81, 101-106. https://doi.org/10.1002/naaq.10076

[37] Crank, K.M., Kientz, J.L. and Barnes, M.E. (2019) An Evaluation of Vertically-Suspended Environmental Enrichment during Rainbow Trout Rearing. North American Journal of Aquaculture, 81, 94-100. https://doi.org/10.1002/naaq.10064

[38] Jones, M.D., Krebs, E., Huysman, N., Voorhees, J.M. and Barnes, M.E. (2019) Rearing Performance of Atlantic Salmon Grown in Circular Tanks with Vertically-Suspended Environmental Enrichment. Open Journal of Animal Sciences, 9, 249-257. https://doi.org/10.4236/ojas.2019.92021 